\title{
Natasza Duraj
}

\section{ZASTAW NA PAPIERACH WARTOŚCIOWYCH A BEZPIECZEŃSTWO FINANSOWE RZEDSIĘBIORSTWA}

\section{WPROWADZENIE}

Jednym z najważniejszych warunków istnienia i kontynuacji działalności przedsiębiorstwa jest posiadanie bezpiecznej sytuacji finansowej. Kształtuje się ona pod wpływem wielu różnorodnych czynników, z których zabezpieczenie wykonania zobowiązań w znaczący sposób wpływa na rozwój działalności gospodarczej wierzyciela i dłużnika. Zdolność do wywiązania się dłużnika z zobowiązań stanowi $\mathrm{m}$. in. o jego wiarygodności i gwarancji prawnych umożliwiających wierzycielowi zaspokojenie jego roszczeń. Zabezpieczenie wykonania zobowiązań może mieć formę zabezpieczeń osobistych, rzeczowych i wekslowych. Może być ono ustanowione zarówno przez wierzyciela, jak i dłużnika lub też osobę trzecią. Nadto, zabezpieczenie może odnosić się do nieomal każdej wierzytelności i na rzecz wierzyciela o obojętnym statusie prawnym ${ }^{1}$.

Celem zasadniczym artykułu jest wskazanie na występowanie relacji między zabezpieczeniem rzeczowym w formie zastawu na papierach wartościowych a bezpieczeństwem finansowym przedsiębiorstwa. Podjęcie rozważań nad związkami zastawu bezpieczeństwem finansowym przedsiębiorstwa wynika nie tylko ze znaczącej roli i znaczenia zastawu we wspieraniu finansowym lecz także z dążenia wierzycieli do zmniejszenia ryzyka lokaty kapitału przy jednoczesnym kształtowaniu przez wierzyciela i dłużnika warunków udzielenia i uzyskania na przykład kredytu inwestycyjnego i obrotowego.

Opracowanie dzieli się na trzy części. W części pierwszej przedstawione są kwestie wskazujące na pojęcie i rodzaje zastawu na papierach wartościowych,

\footnotetext{
* Dr hab., prof. nadzw. UŁ, Uniwersytet Łódzki, Wydział Ekonomiczno-Socjologiczny, Katedra Analizy i Strategii Przedsiębiorstwa.

${ }^{1}$ Zob. W. Katn er (red.), Prawo cywilne $i$ handlowe $w$ zarysie, Kantor Wydawniczy Zakamycze, Kraków 2004, s. 303.
} 
w drugiej podstawowe prawa i obowiązki zastawcy i zastawnika, w trzeciej zaś zawarte są opisy i problemy praktyki gospodarczej odnoszące się do związków występujących między zastawem a bezpieczeństwem finansowym przedsiębiorstwa, w tym przede wszystkim sposoby zabezpieczenia wykonania zobowiązań emitenta obligacji względem obligatariuszy.

\section{POJĘCIE I RODZAJE ZASTAWU NA PAPIERACH WARTOŚCIOWYCH PRZEDSIĘBIORSTWA}

Pojęcie papierów wartościowych nie zostało ściśle zdefiniowane i zazwyczaj wskazania na ich cechy, funkcje oraz regulacje różnią się w zależności od systemu prawnego, w którym zostały emitowane. Stąd też analiza określenia zastawu, jego rodzajów i funkcji wymaga ostrożności w charakteryzowaniu, interpretacji i wnioskowaniu o roli i znaczeniu zastawu na papierach wartościowych w kształtowaniu nie tylko bezpieczeństwa finansowego przedsiębiorstwa.

Generalnie biorąc, papierem wartościowym jest dokument inkorporujący określone prawo w sposób ułatwiający obrót nim. To ułatwienie wynika $\mathrm{m}$. in. z nierozerwalności dwóch praw podmiotowych. Rozporządzenie prawem następuje bowiem przez rozporząazenie dokumentem, którego to prawa istnienie dokument stwierdza. Nie można natomiast spowodować rozporządzenia dokumentem poprzez rozporządzenia prawem ${ }^{2}$. Tym samym obrót dokumentem papierem wartościowym oraz obrót inkorporowanym w nim prawem są jednym i tym samym obrotem.

Przyjmując do rozważań zastaw na korporacyjnych papierach wartościowych, a zwłaszcza zastaw na akcjach, jako formę zabezpieczenia wierzytelności wskazać można, że tego rodzaju zawężenie zakresu analizowanego problemu podyktowane jest głównie przyjętym celem artykułu, który skierowując uwagę na istotę zabezpieczeń rzeczowych wskazuje na majątek dłużnika, z którego wierzyciel może się zaspokoić z pierwszeństwem przed innymi jego wierzycielami i to nawet wówczas, gdy własność przedmiotu zabezpieczenia zostanie przez dłużnika przeniesiona na inną osobę ${ }^{3}$. Jednak z kwestiami zastawu na akcjach wiążą się też problemy prawa poboru, prawa do akcji i prawa pochodne. Zostaną one co prawda przywołane w tekście, lecz tylko w związku z podnoszonymi głównymi nurtami analizy zastawu na akcjach w kontekście jego relacji $\mathrm{z}$ bezpieczeństwem finansowym przedsiębiorstwa.

${ }^{2}$ S. Grzybows ki (red.), System prawa cywilnego. Część ogólna, t. 1, Ossolineum, Wrocław 1985, s. 449, [za:] P. S o k a l, Zastaw zwykty i rejestrowy na akcjach, Wolters Kluwer Polska Sp. z o.o., Warszawa 2011, s. 34 i 35.

${ }^{3}$ E. Gni ewe k, Prawo rzeczowe, Wydawnictwo C. H. Beck, Warszawa 2003, s. 222, [za:] W. Katner (red.), Prawo cywilne $i$ handlowe $w$ zarysie, Kantor Wydawniczy Zakamycze, Kraków 2004, s. 304. 
Zdefiniowanie pojęcia zastawu nie jest łatwe i raczej niemożliwe do ujęcia go w formie syntetycznej i relatywnie prostej wypowiedzi. Trudność ta wynika z różnorodności rodzajów zastawów i regulacji prawnych oraz funkcji spełnianych przez zastaw w obrocie gospodarczym i działalności gospodarczej przedsiębiorstwa.

Z efektów przeprowadzonej analizy literatury przedmiotu można wydobyć i podkreślić bardzo interesujące i ważne określenie pojęcia zastawu, które zostało sformułowane przez I. Heropolitańską. Zdefiniowane przez tę autorkę pojęcie zastawu zawiera obszerne i najważniejsze wskazania na zasadnicze cechy tego rodzaju prawa.

I. Heropolitańska podaje bowiem, że: Zastaw jest to prawo ustanowione na rzecz wierzyciela $w$ celu zabezpieczenia oznaczonej wierzytelności na zbywalnych rzeczach ruchomych, na mocy którego wierzyciel będzie mógł dochodzić zaspokojenia z tych rzeczy bez względu na to, czyja staty się własnościa $i$ z pierwszeństwem przed wierzycielami osobistymi właściciela rzeczy, $w$ wyjatkiem tych, którym z mocy ustawy przystuguje pierwszeństwo szczególne 4 .

Jest to definicja zastawu, którą uznaję za wystarczającą merytoryczną podstawę dalszych rozważań. Wskazuje ona bowiem na zasadnicze cechy zastawu i zarazem pozwala zwrócić uwagę, że zastaw jest:

a) formą zabezpieczenia wierzytelności, dającą wierzycielowi pierwszeństwo zaspokojenia przed wierzycielami osobistymi właściciela przedmiotu;

b) prawem, na mocy którego wierzyciel może dochodzić zaspokojenia z przedmiotu zastawu bez względu na to czyją stał się on własnością;

c) czynnością realną, co oznacza, że sama umowa nie wystarcza do powstania zastawu pomimo, że w wyniku jej zawarcia między właścicielem rzeczy a wierzycielem, zastawca zobowiązuje się do wydania zastawnikowi - wierzycielowi, bądź osobie trzeciej, rzeczy, na którą strony się zgodziły. Konieczne jest bowiem rzeczywiste wydanie rzeczy wierzycielowi, którą zastawnik po wygaśnięciu stawu powinien zwrócić zastawcy;

d) ograniczonym prawem rzeczowym ustanowionym dla zabezpieczenia wierzytelności. Jest ono ustanowione kodeksem cywilnym tylko dla zastawu na rzeczach ruchomych (art. 306-326) oraz zastawu na prawach zbywalnych, które są przypisane do akcji i obligacji ${ }^{5}$ (art. 327-335).

e) wyrazem temporalnego współistnienia wierzytelności i zastawu, co oznacza, iż zastaw może powstać na istniejącej wierzytelności i zakończyć swoje istnienie z chwilą zaspokojenia wierzytelności. Dotyczy tylko wierzytelności

${ }^{4}$ I. He ropolitań s ka, Prawne zabezpieczenie wierzytelności, [w:] K. K rec z mańs ka- Gigol (red.), Aktywne zarzqdzanie ptynnościq finansowa przedsiębiorstwa, Difin, Warszawa 2010, s. 198.

${ }^{5}$ Kodeks cywilny reguluje dwa rodzaje zastawu: zastaw na rzeczach ruchomych (art. 306 -326) oraz zastaw na prawach (art. 327-335). Możliwość ustanowienia zastawu na udziałach przewiduje art. 180 kodeksu spółek handlowych. Stanowi on, iż zastawienie udziału powinno być dokonane $\mathrm{w}$ formie pisemnej z podpisami notarialnie poświadczonymi. 
zabezpieczonych finansowo na aktywach zastawnika na rzecz zastawcy, który jest właścicielem rzeczy na której ustanawia się zastaw.

Sformułowane pojęcie zastawu oraz wyszczególnione jego cechy pozwalają określić zastaw jako określony rodzaj wierzytelności zabezpieczonej w formie określonej rzeczy lub papieru wartościowego przez wierzyciela, który udzielił zastawcy kredytowego wsparcia finansowego. Przedsiębiorcy mogą obciążać akcje, a w zasadzie prawa w nich inkorporowane będące ich własnością, zastawem kodeksowym, zastawem rejestrowym i zastawem finansowym.

Zdefiniowanie zastawu jako określonego rodzaju ograniczonego prawa rzeczowego wymaga wskazania, że prawa rzeczowe należą do majątkowych i bezwzględnych praw podmiotowych oraz że ograniczone prawa rzeczowe są ustanawiane na rzeczy cudzej i powstają drogą umów. Można powiedzieć, że zastaw to wierzytelność zabezpieczona przez zastawnika, który udzielił zastawcy pożyczki, a jej spłatę zabezpiecza określona rzecz, bądź dany papier wartościowy. Wraz z chwilą zaistnienia zastawu dłużnik - zastawca - staje się dłużnikiem rzeczowym lub finansowym.

Praktyka zastawu na akcjach dowodzi istnienia sytuacji, w których posiadaczem dokumentu akcji jest zastawnik, bądź zastawca lub osoba trzecia. Każda ze stron posiada określone prawa i obowiązki, które legitymizuje Ustawa z dnia 6 grudnia 1996 r. o zastawie rejestrowym i rejestrze zastawów (DzU 1996, nr 149, poz. 703, z późn. zm.).

Zastaw jest jednym z rodzajów zabezpieczeń rzeczowych wierzytelności, w którym odpowiedzialność dłużnika odnosi się tylko do ściśle określonych składników majątku ${ }^{6}$ i rozciagga się tylko na określony czas. Byt zastawu zależy od istnienia wierzytelności oraz zabezpieczonych rzeczy i praw. Ma on charakter temporalny. Zastaw jest skuteczny wobec wierzycieli zastawcy, jeżeli umowa zawarta jest na piśmie z datą pewną. Jego czas jest wyznaczony datą wpisu do rejestru zastawów oraz zaspokojeniem wierzytelności przywracającej właścicielowi przedmiot zastawu. Wraz z zaspokojeniem wierzyciela zastaw wygasa.

Zależność zastawu od wierzytelności wynika z zasady akcesoryjności zastawu$^{7}$. Konsekwencją realizacji zasady akcesoryjności zastawu jest wymóg istnienia zabezpieczanej wierzytelności w chwili ustanowienia prawa. W praktyce stosuje się wyjątek od tej zasady. Istnieje bowiem możliwość zabezpieczenia wierzytelności przyszłej lub wierzytelności warunkowej, a zatem takiej wierzytelności, która nie istnieje jeszcze w chwili zawarcia umowy zastawniczej ${ }^{8}$. Tego

\footnotetext{
${ }^{6}$ M. Leśn i a k, Zastaw bez przeniesienia posiadania przedmiotu zastawu, Kantor Wydawniczy Zakamycze, Kraków 2004, s. 15-16, [za:] S. Gr z y b o w s k i, System prawa cywilnego. Prawo zobowiqzań - czesść ogólna, t. III, cz. 1, Wrocław-Warszawa 1981, s. 66.

${ }^{7}$ J. Gołaczyńs ki, Zastaw na rzeczach ruchomych, Wydawnictwo C. H. Beck, Warszawa 2002, s. 139.

${ }^{8}$ G. S i kor s ki, Sytuacja prawna zastawnika w prawie polskim, Doktoraty Wydziału Prawa i Administracji Uniwersytetu Mikołaja Kopernika w Toruniu, Toruń 2010, s. 94. Por. Ustawa z dnia 19 grudnia 1996 r. o zastawie rejestrowym i rejestrze zastawów, DzU 2006, nr 149,
} 
rodzaju rozwiązanie uelastycznia i wzbogaca rozwiązania zabezpieczeń rzeczowych i może być przypisane zarówno do zastawu zwykłego, jak i do zastawu specjalnego, w tym też zatem do zastawu rejestrowego i finansowego 9 .

W zastawie zwykłym przedmiot zastawu jest wydawany zastawnikowi i przez to wzrasta skuteczność tego zastawu. W zastawie specjalnym zastawca nie wydaje przedmiotu zastawu zastawnikowi. W przypadku zaś zastawu rejestrowego nie ma konieczności przeniesienia posiadania ani wydania przedmiotu zastawu zastawnikowi. Przedmiot ten może - zgodnie z wolą stron wyrażoną w umowie zastawniczej - pozostać w posiadaniu zastawcy oraz osoby trzeciej za jej zgodą. Od zastawu zwykłego zastaw rejestrowy różni się przede wszystkim tym, że przedmiot zastawu rejestrowego może pozostać w posiadaniu i faktycznym władaniu zastawcy, podczas gdy przedmiot zastawu zwykłego musi by co do zasady wydany zastawnikowi lub osobie trzeciej. Takie rozwiązanie leży w interesie obu stron umowy. Zastawca zachowuje bowiem możliwość dalszego korzystania z przedmiotu zastawu. W razie pozostawienia przedmiotu zastawu w rękach osoby trzeciej może ona ponosić ewentualną odpowiedzialność wobec wierzyciela za stan przedmiotu zabezpieczenia.

G. Sikorski wskazuje, że zastaw nie stanowi klarownej konstrukcji ze względu na istnienie wielu rodzajów zastawu, jak również z uwagi na przyjęte przez ustawodawcę różne rozwiązania praktyczne ${ }^{10}$. Tym nie mniej w literaturze przedmiotu dominuje pogląd, że celem zastawu zwykłego oraz wszystkich typów zastawu bez przeniesienia posiadania przedmiotu zastawu jest przede wszystkim zabezpieczenie wierzytelności. Taki pogląd reprezentuje $\mathrm{m}$. in. M. Leśniak ${ }^{11}$, przywołując w tym zakresie opinie J. Skapskiego ${ }^{12}$ i E. Gniewka ${ }^{13}$.

W polskim systemie prawnym wyróżnia się trzy następujące rodzaje zastawów, a mianowicie:

a) zastaw,

b) zastaw rejestrowy,

c) zastaw skarbowy oraz

d) zastaw finansowy (zob. tab. 1).

Podstawę prawną ustanawiania zastawu, zastawu rejestrowego i zastawu skarbowego tworzą różnorodne przepisy prawa, które w sposób jednoznaczny wskazują na złożoność problemów zabezpieczenia wykonania zobowiązań oraz ich egzekucji.

poz. 703 z późn. zm., art. 3 ust. 2 pkt 4 i art. 6; Ustawa z dnia 23 kwietnia 1964 r. - Kodeks cywilny, DzU 1964, nr 16, poz. 93 z późn. zm., art. 306 § 2; Ustawa z dnia 2 kwietnia 2004 r. o niektórych zabezpieczeniach finansowych, DzU 2004, nr 91, poz. 871, z późn. zm., art. 1.

${ }^{9}$ G. S i korski, op. cit., s. 94.

${ }^{10}$ Ibidem, s. 20.

${ }^{11}$ M. Le śni a k, op. cit., s. 61.

${ }^{12} \mathrm{~J} . \mathrm{S}$ k ąp s ki, Zastaw na rzeczach ruchomych wedtug kodeksu cywilnego. Zagadnienia wybrane, ,Studia Cywilistyczne” 1966, t. VIII, s. 152.

${ }^{13}$ E. Gni ew ek, op. cit., s. 227. 


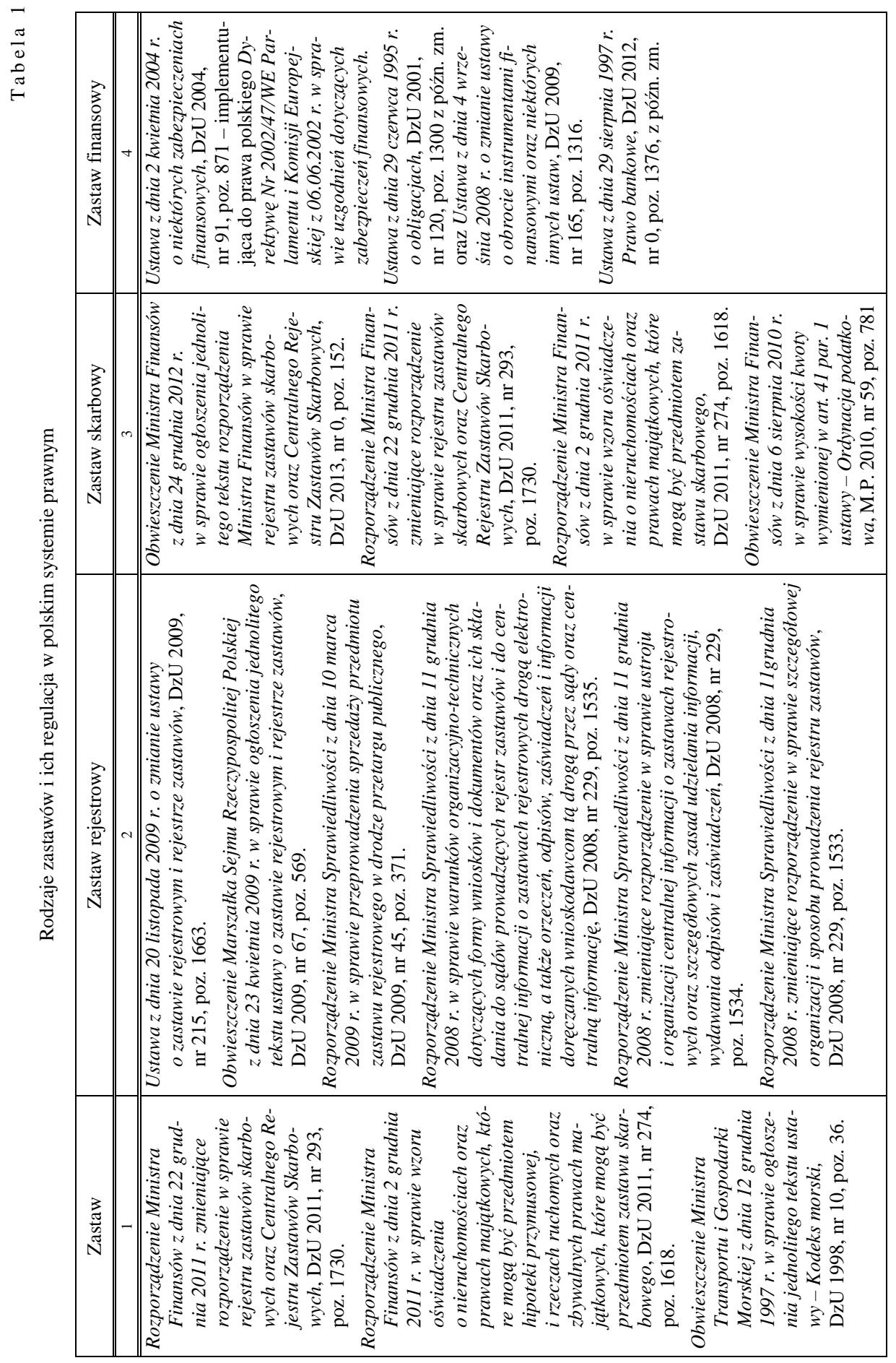




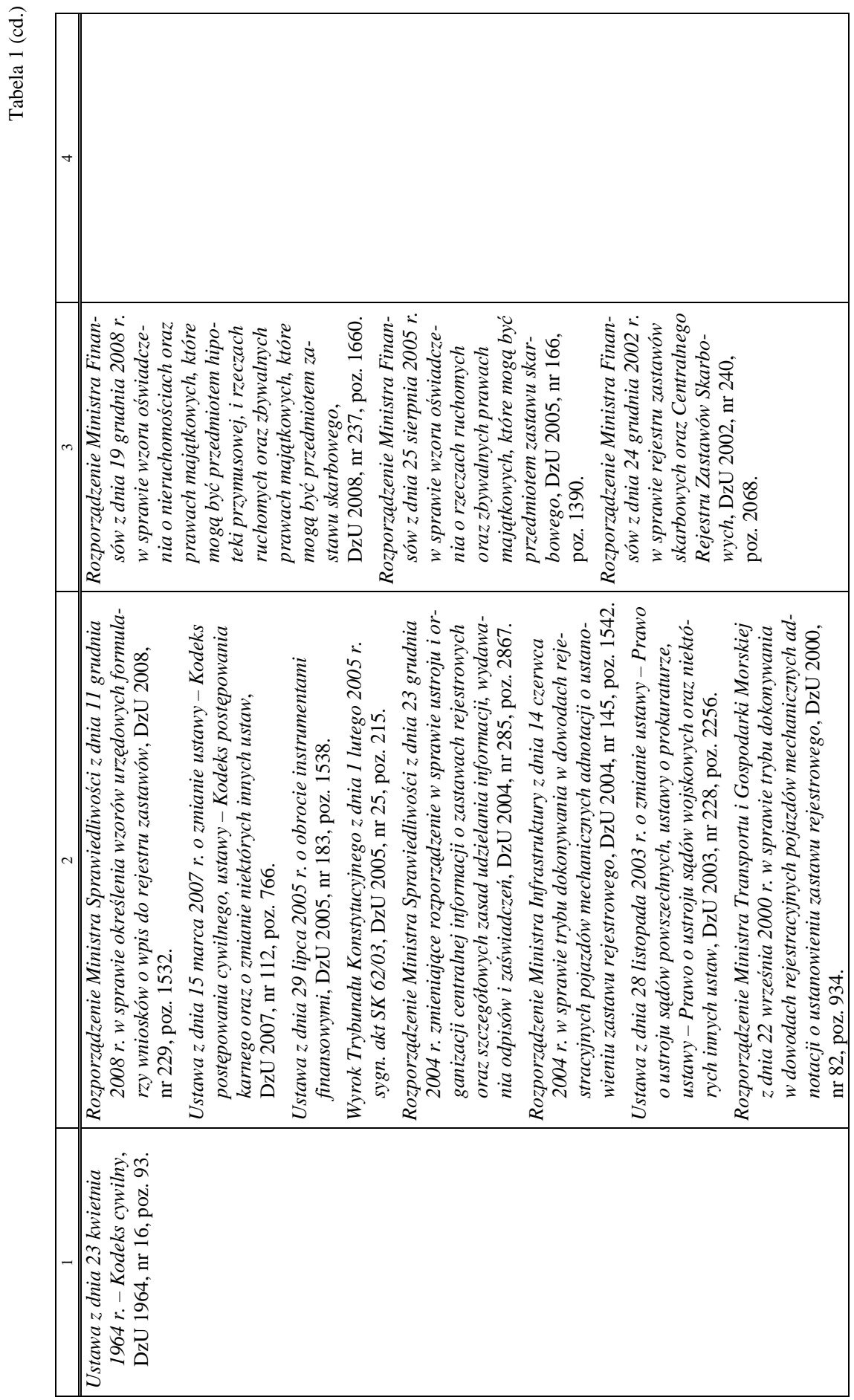




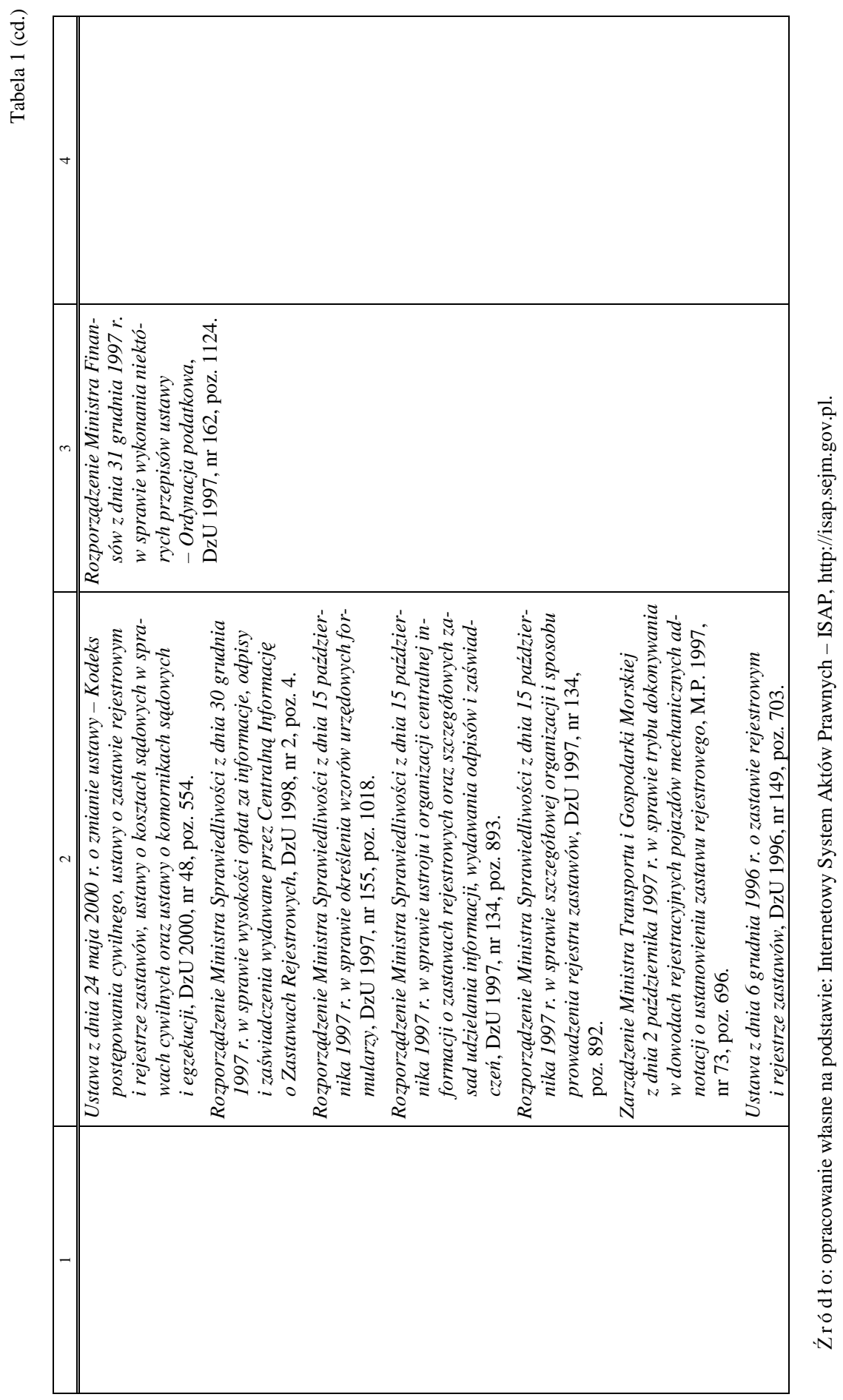


Czwartym wyróżnionym rodzajem zastawu jest zastaw finansowy, który jest szczególnym rodzajem zastawu obciążającego akcje. Zastaw ten ukształtowany został regulacjami zasad ustanawiania i wykonywania zabezpieczeń na środkach pieniężnych lub instrumentach finansowych wierzytelności pieniężnych lub wierzytelności, w których świadczenie polega na dostarczeniu wierzycielowi określonych instrumentów finansowych. Należą do nich na przykład akcje i obligacje na świadczenia pieniężne, bankowe papiery wartościowe.

\section{RELACJE ZASTAWCA - ZASTAWNIK A BEZPIECZEŃSTWO FINANSOWE PRZEDSIĘBIORSTWA}

Za szczególny rodzaj zastawu uznać należy zastaw rejestrowy. Został on wprowadzony do praktyki gospodarczej na mocy przepisów Ustawy $z$ dnia 19 grudnia 1996 r. o zastawie rejestrowym i rejestrze zastawów ${ }^{14}$. Zastaw rejestrowy zastapił bankowy zastaw rejestrowy. Ustawa o zastawie rejestrowym i rejestrze zastawów wprowadziła nowe rozwiązania w systemie prawa materialnego i procesowego, dając zastawnikowi możliwość obciążenia zastawem rzeczy lub praw.

Zastaw rejestrowy powstaje dopiero $\mathrm{z}$ chwilą dokonania odpowiedniego wpisu do rejestru zastawów. Do ustanowienia zastawu rejestrowego jest wymagane zawarcie umowy o ustanowienie zastawu (tzw. umowa zastawnicza), w formie pisemnej pod rygorem nieważności oraz wpis do rejestru zastawów. Stronami umowy zastawniczej są: osoba uprawniona do rozporządzania przedmiotem zastawu oraz wierzyciel.

Zastawnik w zastawie rejestrowym jest przedsiębiorcą i na jego rzecz ustanawia się zastaw dla zabezpieczenia wierzytelności.

Zastaw rejestrowy wygasa w przypadku:

- zaspokojenia zabezpieczonej nim wierzytelności,

- rozwiązania umowy zastawniczej przez jej strony oraz

- wykreślenie zastawu rejestrowego z rejestru zastawów.

W przypadku zastawu rejestrowego nie jest konieczne przeniesienie posiadania ani wydanie dokumentu akcji zastawnikowi. Akcja może pozostać w posiadaniu zastawcy lub osoby trzeciej. O wyborze rozwiązania decyduje wola stron wyrażona w umowie zastawniczej. Jeśli wierzytelność zabezpieczona zastawem jest wierzytelnością przyszłą lub warunkową, wówczas w umowie tej należy podać najwyższą sumę zabezpieczenia.

Ustawa z dnia 2 kwietnia 2004 r. o niektórych zabezpieczeniach finansowych wprowadziła nową kategorię zabezpieczeń, tzw. zabezpieczenia finansowe. Zabezpieczenia finansowe są ustanawiane w drodze umowy i ich ustano-

\footnotetext{
${ }^{14}$ Ustawa z dnia 19 grudnia 1996 r..., op. cit.
} 
wienie odnotowuje się na rachunku papierów wartościowych. Podstawowymi rodzajami zabezpieczeń finansowych są: zastaw finansowy, blokada finansowa (blokada ustanawiana na rachunku papierów wartościowych) oraz przeniesienie akcji, także z zastrzeżeniem odkupu, przez ustanawiającego zabezpieczenie na przyjmującego zabezpieczenie.

Jeśli zastaw został ustanowiony na akcji, która ma formę dokumentu, wówczas istnieje obowiązek wydania zastawnikowi dokumentu tejże akcji. Natomiast w sytuacji, gdy zastaw ustanowiony jest na akcjach zdematerializowanych, wówczas informacja o ustanowieniu zastawu odnotowywana jest na rachunku papierów wartościowych.

Wydaje się, że w rozważaniach nad zastawem na akcjach należałoby podkreślić potrzebę pełniejszego spojrzenia na formę akcji, będących przedmiotem zastawu. Wyróżniając bowiem akcje mające formę dokumentu oraz formę zdematerializowaną i tym samym będące zapisanymi na właściwym rachunku, należałoby podkreślić, że forma akcji posiada znaczenie dla egzekucji uprawnień majątkowych zastawnika zastawu na akcjach. Dostrzec można występowanie zróżnicowanych warunków skutecznego ustanawiania zastawu na akcje w formie dokumentu $\mathrm{i} \mathrm{w}$ formie zdematerializowanej. W tym ostatnim przypadku zmniejszenie ryzyka zastawnika może mieć miejsce, gdy nastąpi blokada obciążonych akcji przez jednostkę prowadząca rachunek papierów wartościowych. Blokada ta jest utrzymywana przez cały okres trwania zastawu i w tym okresie obciążone akcje nie mogą być przedmiotem sprzedaży, ani nie mogą być też umorzone ${ }^{15}$.

W przypadku akcji posiadających formę dokumentu, egzekucja może odbyć się przez sprzedaż akcji lub też z dochodów dywidendowych. Natomiast w przypadku akcji zdematerializowanych, egzekucja w pierwszej kolejności dotyczy środków pieniężnych, które zgromadzone zostały na rachunku pieniężnym i który związany jest $\mathrm{z}$ rachunkiem papierów wartościowych.

Ustanowienie zastawu rejestrowego odnotowywane jest także na rachunku danych akcji. Zastawem rejestrowym może zostać obciążony cały określony zbiór akcji, obejmujący na przykład wszystkie akcje danej lub danych serii.

Za jedną z zasadniczych zalet zastawu rejestrowego należy uznać możliwość wskazania przez zastawnika i zastawcę w umowie zastawu innych alternatywnych sposobów zaspokojenia wierzytelności zastawnika przez zastawcę. Tymi sposobami może być: przejęcie zastawionych akcji na własność czy też sprzedaż zastawionych akcji $\mathrm{w}$ drodze przetargu publicznego, zleconego do przeprowadzenia przez notariusza lub komornika. W przypadku zaspokojenia w drodze przejęcia akcji posiadających formę dokumentu, przejęcie tych papie-

${ }^{15}$ Szerzej zob. A. P i elo ch, Restrukturyzacja kapitałowa przedsiębiorstw z wykorzystaniem operacji buy-back, [w:] J. D u raj (red.), Instrumenty kształtowania dochodowości i rentowności przedsiębiorstwa, ,Acta Universitatis Lodziensis”, Folia Oeconomica 278, Wydawnictwo Uniwersytetu Łódzkiego, Łódź 2013, s. 115 i nast. 
rów wartościowych następuje z chwilą złożenia przez zastawcę zawiadomienia o przejęciu. Natomiast w przypadku akcji zdematerializowanych, ich przejęcie realizuje się, gdy dom maklerski na żądanie zastawnika przeniesie zastawione akcje na jego rachunek.

Dwustronny charakter umowy o zastawie skutkuje określonymi prawami i obowiązkami zastawcy i zastawnika. Zawarte w tab. 2 prawa i obowiązki zastawcy i zastawnika akcji wskazują na podstawowe regulacje prawne pomiędzy równoprawnymi podmiotami prawa, które wykonują względem siebie oraz osób trzecich określone obowiązki.

Są to podstawowe prawa i obowiązki podmiotów zaangażowanych w udzielanie wsparcia finansowego (wierzycieli) jednostkom wspieranym przez zastawnika, który w rachunku ekonomicznej efektywności uwzględnia wiele zmiennych decydujących o udzieleniu wsparcia finansowego z jednoczesnym wykorzystaniem zastawu na określonych papierach wartościowych.

Zawarty w tab. 2 zbiór praw zastawnika zastawu na akcjach wskazuje na jego uprawnienia majątkowe. Zasada przyznawania pożytków zastawnikowi obowiązuje w przypadku zastawu kodeksowego i zastawu finansowego. Jeśli pożytkiem tym jest wypłacana dywidenda $z$ akcji, wówczas zastawnikowi przysługuje roszczenie do spółki o wypłatę dywidend, co do których dzień wypłaty przypada na okres trwania zastawu, bez względu na to, czy zastaw nadal trwa. Natomiast w przypadku zastawu rejestrowego wszystkie pożytki przypadają zastawcy.

Ustawa z dnia 2 kwietnia 2004 r. o niektórych zabezpieczeniach finansowych wprowadziła nową kategorię zabezpieczeń, tzw. zabezpieczenia finansowe. Zabezpieczenia finansowe są ustanawiane w drodze umowy. Fakt ich ustanowienia odnotowuje się na rachunku papierów wartościowych. Zabezpieczenia finansowe mogą być ustanawiane, gdy stroną umowy nie jest osoba fizyczna oraz gdy przynajmniej jedna ze stron umowy jest podmiotem prowadzącym działalność na rynku finansowym. Rodzajami zabezpieczeń finansowych są: zastaw finansowy, blokada finansowa (blokada ustanawiana na rachunku papierów wartościowych) oraz przeniesienie akcji, także z zastrzeżeniem odkupu, przez ustanawiającego zabezpieczenie na przyjmującego zabezpieczenie.

Jeśli zastaw został ustanowiony na akcji, która ma formę dokumentu, wówczas istnieje obowiązek wydania zastawnikowi dokumentu tejże akcji. Natomiast w sytuacji, gdy zastaw ustanowiony jest na akcjach zdematerializowanych, wówczas informacja o ustanowieniu zastawu odnotowywana jest na tym rachunku.

I tak, w przypadku akcji posiadających formę dokumentu, egzekucja może odbyć się przez sprzedaż lub też z dochodów, jakie przynosi dana akcja, takich jak np. dochody z dywidendy. Natomiast w przypadku akcji zdematerializowanych, egzekucja w pierwszej kolejności dotyczyć będzie środków pieniężnych, jakie zgromadzone zostały na rachunku pieniężnym, który związany jest z rachunkiem papierów wartościowych. 
Treść stosunku cywilnoprawnego zastawcy i zastawnika akcji

\begin{tabular}{|c|c|c|}
\hline $\begin{array}{l}\text { Wyszcze- } \\
\text { gólnienie }\end{array}$ & Zastawca & Zastawnik \\
\hline 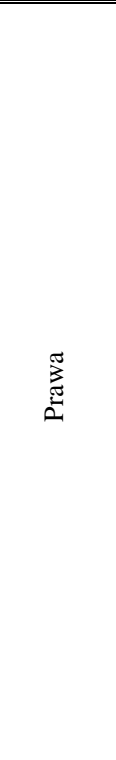 & $\begin{array}{l}\text { Korzystania z przedmiotu zastawu rejestro- } \\
\text { wego zgodnie z jego społeczno- } \\
\text {-gospodarczym przeznaczeniem; } \\
\text { Roszczenia o odszkodowanie z tytułu utraty, } \\
\text { zniszczenia, uszkodzenia lub obniżenia } \\
\text { wartości przedmiotu zastawu rejestrowe- } \\
\text { go - w tym akcji (art. } 10 \text { ust. } 2 \text { u.z.r.r.z.); } \\
\text { Pobieranie pożytków, jeżeli z umowy nie } \\
\text { wynika co innego; } \\
\text { Wyboru pozaegzekucyjnego sposobu zaspo- } \\
\text { kojenia się przez zastawnika. W wypadku } \\
\text { gdy akcje będą w posiadaniu zastawnika, } \\
\text { zastawcy przysługiwać może roszczenie } \\
\text { o wydanie akcji w celu ich sprzedaży } \\
\text { w drodze przetargu publicznego; } \\
\text { Zachowania prawa poboru akcji nowej } \\
\text { emisji, uprawnienie do jego wykonania } \\
\text { pozostaje przy zastawcy; } \\
\text { Nowe akcje przypadają zastawcy; } \\
\text { Utrzymania prawa głosu z obciążonych } \\
\text { akcji. }\end{array}$ & $\begin{array}{l}\text { Pobierania akcji, gdy akcja zostanie wydana; } \\
\text { Pobierania pożytków przynoszonych przez } \\
\text { przedmiot zastawu (np. pobieranie dywi- } \\
\text { dendy), jeżeli z umowy nie wynika co } \\
\text { innego }{ }^{16} \text {; } \\
\text { Udziału w majątku likwidowanej spółki; } \\
\text { Zaspokojenia się z określonym pierwszeń- } \\
\text { stwem, gdy wierzytelność jest wymagana; } \\
\text { Zaspokojenia się w trybie pozaegzekucyj- } \\
\text { nym, jeżeli w umowie strony zastrzegły } \\
\text { taką możliwość; } \\
\text { Zastawnikowi uprawnionemu do wykony- } \\
\text { wania prawa głosu przysługuje prawo do: } \\
\text { - udziału w walnym zgromadzeniu akcjo- } \\
\text { nariuszy, } \\
\text { - uzyskiwania informacji od zarządu } \\
\text { w sprawach spółki w trakcie zgroma- } \\
\text { dzenia; } \\
\text { Sprzedaży zastawionych akcji w drodze } \\
\text { przetargu publicznego z zawiadomieniem } \\
\text { zastawcy na piśmie. }\end{array}$ \\
\hline 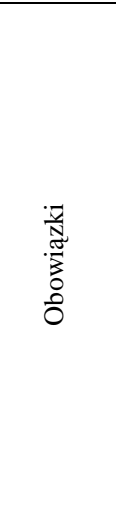 & $\begin{array}{l}\text { Dbałość o zachowanie przedmiotu zastawu } \\
\text { rejestrowego w stanie nie gorszym niż } \\
\text { wynikający z prawidłowego używania; } \\
\text { Umożliwienie zastawnikowi zbadanie stanu } \\
\text { przedmiotu zastawu rejestrowego w wy- } \\
\text { znaczonym przez zastawnika terminie }{ }^{17} \text {; } \\
\text { Pobierania i zaliczania pożytków na poczet } \\
\text { wierzytelności i związanych z nią rosz- } \\
\text { czeń w wypadku odmiennej umowy. } \\
\text { Po wygaśnięciu zastawu zobowiązany } \\
\text { jest założyć zastawnikowi rachunek } \\
\text { (art. } 319 \text { k.c.); } \\
\text { Poddania się egzekucji w razie konieczności } \\
\text { zaspokojenia się przez zastawnika } \\
\text { (art. } 312 \text { k.c.). }\end{array}$ & $\begin{array}{l}\text { Pobierania i zaliczania pożytków na poczet } \\
\text { wierzytelności i związanych z nią rosz- } \\
\text { czeń. Po wygaśnięciu zastawu zobowią- } \\
\text { zany jest złożyć zastawcy rachunek; } \\
\text { Obowiązek czuwania nad wydaną mu akcją, } \\
\text { jeżeli strony postanowiły o pozostawieniu } \\
\text { akcji w posiadaniu przez zastawnika }{ }^{18} \text {; } \\
\text { Zwrotu zastawcy nadwyżki kwoty uzyskanej } \\
\text { przez zastawnika ze sprzedaży akcji od } \\
\text { wartości wierzytelności. }\end{array}$ \\
\hline
\end{tabular}

Źródło: opracowanie własne na podstawie: Ustawy z dnia 19 grudnia 1996 r. o zastawie rejestrowym i rejestrze zastawów, DzU 2006, nr 149, poz. 703 z późń. zm. oraz P. S o k a l, Zastaw zwykty i rejestrowy na akcjach, Wolters Kluwer Polska Sp. z o.o., Warszawa 2011, s. 214.

${ }^{16}$ Pożytkiem akcji, a dokładnie praw w nich inkorporowanych, jest w szczególności wypłacana przez spółkę dywidenda przypadająca na akcję.

${ }^{17}$ Ustawa z dnia 19 grudnia 1996 r..., op. cit., art. 11 ust. 1. Przepis ten stosuje się odpowiednio do osoby trzeciej, w której posiadaniu znajduje się przedmiot zastawu rejestrowego.

${ }^{18}$ P. S o ka l, op. cit., s. 214. 
Ustanowienie zastawu, mające miejsce przez podpisanie umowy zastawu oraz wpis do sądowego rejestru zastawów, odnotowywane jest także na rachunku danych akcji. Zastawem rejestrowym może zostać obciążony cały określony zbiór akcji, obejmujący na przykład wszystkie akcje danej serii.

Zastaw rejestrowy tworzy możliwość wskazania przez zastawnika i zastawcę w umowie zastawu innych alternatywnych sposobów zaspokojenia wierzytelności zastawnika przez zastawcę. Możliwości te dotyczą m. in. przejęcia przez zastawnika zastawionych akcji na własność, sprzedaży zastawionych akcji w drodze przetargu publicznego, zleconego do przeprowadzenia przez notariusza lub komornika. W przypadku zaspokojenia w drodze przejęcia akcji posiadających formę dokumentu, przejęcie tych papierów wartościowych następuje z chwilą złożenia przez zastawcę zawiadomienia o przejęciu. Natomiast w sytuacji objęcia zastawem akcji zdematerializowanych, ich przejęcie ma miejsce, gdy dom maklerski przeniesie zastawione akcje na żądanie zastawnika na jego rachunek.

\section{ZWIĄZKI MIĘDZY ZASTAWEM NA PAPIERACH WARTOŚCIOWYCH A BEZPIECZEŃSTWEM FINANSOWYM PRZEDSIĘBIORSTWA}

Za zasadniczą przesłankę podjęcia rozważań nad relacjami między zastawem na papierach wartościowych a bezpieczeństwem finansowym przedsiębiorstwa można uznać hipotezę stwierdzająca, że bezpieczeństwo finansowe przedsiębiorstwa ma miejsce, gdy posiada ono zadawalające finansowe warunki kontynuacji i perspektywy rozwoju działalności gospodarczej ${ }^{19}$. Warunki te zdeterminowane są wieloma złożonymi i różnorodnymi czynnikami, które dotyczą m. in. sytuacji finansowo-majątkowej przedsiębiorstwa, jego efektywności ekonomicznej i kapitału relacyjnego z wierzycielami.

Potrzeby sfinansowania inwestycji oraz wzrostu wartości rynkowej i dochodu całkowitego przedsiębiorstwa uznane mogą być za zasadnicze motywy działalności wierzycieli i właścicieli, którzy decydują się na poniesienie określonego ryzyka dla osiągnięcia satysfakcjonujących stóp zwrotu Jest ono nierównomiernie rozłożone między zastawnika i zastawcę. Ta asymetria ryzyka ma miejsce w każdym przypadku podejmowania i realizacji określonego przedsięwzięcia. W przypadku zaś emisji obligacji i pozostałych papierów wartościowych posiada szczególnie wyraźne relacje z bezpieczeństwem finansowym przedsiębiorstwa.

${ }^{19}$ Pojęcie bezpieczeństwa przedsiębiorstwa można zdefiniować jako proces i/lub ogół warunków pozyskiwania, gromadzenia i wykorzystywania środków finansowych zapewniający kontynuację działalności przedsiębiorstwa oraz finansowe warunki jego rozwoju. Zob. N. A. D u raj, Wieloczynnikowa koncepcja modelu bezpieczeństwa finansowego przedsiębiorstwa, [w:] J. D u $\mathrm{raj}$, A. S ajnóg (red.), Ekonomiczne i pozaekonomiczne czynniki zarzadzania wartościa przedsiębiorstwa, Wydawnictwo Uniwersytetu Łódzkiego, Łódź 2013, s. 65. 
Przedsiębiorstwo może bowiem emitować obligacje niezabezpieczone i zabezpieczone określonymi aktywami. Jeśli obligacje są zabezpieczone, wówczas tworzą one mniejsze ryzyko dla obligatariuszy niż obligacje zwykłe niezabezpieczone. Stąd też obligacje zabezpieczone oferują niższe stopy dochodowości niż obligacje niezabezpieczone. Objęcie niezabezpieczonych obligacji wynika $\mathrm{z}$ ufności obligatariuszy $\mathrm{w}$ znaczącą siłę zarobkowania przedsiębiorstwa, co wyrażone może być $\mathrm{m}$. in. prawdopodobnymi znaczącymi wzrostami operacyjnego zysku przedsiębiorstwa oraz operacyjnych przepływów pieniężnych. Niezabezpieczone aktywami obligacje tworzą obligatariuszowi znaczące ryzyko nie wypełnienia umowy obligacyjnej, gdy przedsiębiorstwo staje się bankrutem. Jest on tzw. zwykłym wierzycielem przedsiębiorstwa, który nie posiada żadnych priorytetów ${ }^{20}$. Znajduje się on $w$ grupie tych wierzycieli oczekujących na zaspokojenie swych roszczeń, którzy tworzyć mogą ostatnią grupę wierzycieli oczekujących w kolejce na odzyskanie swoich należności. Jeśli nie odzyskają w procesie likwidacji majątku określonej części swoich roszczeń, wówczas mogą oni ponieść znaczącą stratę.

Obojętny status prawny wierzycieli raczej nie ma miejsca w systemie stosowanych zabezpieczeń wykonania zobowiązań wskutek poszukiwania przez nich rozwiązań minimalizujących ryzyko finansowe. Nadto w systemie tym ma miejsce zróżnicowanie prawne pozycji podmiotów uprawnionych w dochodzeniu zabezpieczonych wierzytelności. Egzekucyjne uprzywilejowanie mają banki.

Zabezpieczeniem wykonania zobowiązań z obligacji są określone aktywa przedsiębiorstwa, które obligatariusz może otrzymać, gdy emitent obligacji nie wypełni zobowiązań wynikających z obligacji. Obligacja może być zabezpieczona nieruchomością czy papierami wartościowymi przedsiębiorstwa (wspomnianymi wcześniej akcjami, prawem poboru, prawem do akcji, prawem pochodnych papierów wartościowych itp. $)^{21}$.

Niezabezpieczone wierzytelności pozostawiają dłużnikom zdecydowanie większą swobodę gospodarowania wszystkimi środkami finansowymi, przyczy-

${ }^{20}$ Taką obligacją jest na przykład obligacja zwykła o stałym oprocentowaniu do chwili wykupu (ang. straightbond). Zob. Z. B od i e, A. Kan e, A. J. Markus, Investments, R. D. Irwin, Inc. Homewood, Boston 1998, s. 405.

${ }^{21} \mathrm{Na}$ amerykańskim rynku papierów wartościowych występuje wiele rodzajów zabezpieczeń wykonania zobowiązań z obligacji. Należą do nich $\mathrm{m}$. in. obligacja zabezpieczona innym papierem wartościowym (ang. collateralbond), obligacja z gwarancją instytucji powierniczej (ang. collateral trust bond), obligacja zabezpieczona majątkiem ruchomym, do którego prawo posiada powiernik (ang. equipment trust bond), obligacje zabezpieczone na nieruchomościach (ang. mortagebonds). Natomiast w przypadku zabezpieczenia obligacji na dobrach inwestycyjnych noszą one nazwę equipmentobligationbond. Mortagebonds mają pierwszeństwo żądania w przypadku bankructwa emitenta obligacji. Zob. Z. Bodie, A. Kane, A. J. Markus, Essentials of investments, R. D. Irwin, Inc. Homewood, Boston 1992, s. 346.

W terminologii anglosaskiej zabezpieczenie zobowiązań emitenta obligacji na akcjach i jego innych papierach wartościowych nosi nazwę collateral trust bond. W przypadku zabezpieczenia na nieruchomości obligacja jest nazwana mortagebond. Zob. Z. B o di e, A. K a n e, A. J. M ark u s, Essentials of..., op. cit., s. 346. 
niając się do wzrostu elastyczności działania przedsiębiorstwa. W przypadku zabezpieczenia wykonania zobowiązania z tytułu wyemitowanych obligacji, ich emitent nie tylko zabezpiecza określone aktywa, lecz także podporządkowuje inne prawne wymagania odnoszące się do aktywów, osiągniętego zysku, tworzy fundusz amortyzacji (nawet gdy stanie się bankrutem), z którego wypłaca zobowiązania $\mathrm{z}$ obligacji. Może on oferować także inne formy i sposoby ochrony interesów obligatariuszy ${ }^{22}$. Obligatariusze mogą otrzymać obligacje z dodatkowym zabezpieczeniem wierzytelności. Wartość tego zabezpieczenia wpływa na wysokość stopy odsetek kuponowych od obligacji i z reguły większemu zabezpieczeniu obligacji towarzyszy mniejsza stopa odsetek kuponowych.

Mogą być to także klauzule zmierzające do zabezpieczenia wykonania zobowiązań, które:

a) ograniczają emisje nowych długów,

b) limitują wypłaty dywidendy,

c) dotyczą fuzji i połączeń przedsiębiorstw,

d) posiadają ograniczenia $\mathrm{w}$ dysponowaniu aktywami przedsiębiorstwa ${ }^{23}$ oraz

e) ograniczają zawarcie nowych umów leasingowych ${ }^{24}$.

Na ogół też wzrost wartości zabezpieczenia wykonania zobowiązań emitenta obligacji wzrasta wraz ze spadkiem jakości obligacji. Emitenci o wysokich ratingach obligacji mogą nie oferować zabezpieczenia obligatariuszom, gdyż ich działalność nie jest narażona na ryzyko i zagrożenie bankructwem.

Przedsiębiorstwa dla ochrony interesów obligatariuszy przed szkodą stosują klauzule podporządkowania, które ograniczają wartość dodatkowych zobowiązań i/lub zabezpieczeń wykonania zobowiązań. Dodatkowo mogą one respektować zasadę pierwszeństwa spłaty istniejących długów przed długiem nowym $\mathrm{i} /$ lub posiadać charakter obligacji z odłożonym terminem spłaty. W pierwszym przypadku obligatariusze zaliczani do seniorów są zaspakajani przed obligatariuszami młodszymi, dla których wykonanie zobowiązania może rozpocząć się po całkowitym spłaceniu „seniorów”. Ta zasada, określana często jako mefirstrule, wyraźnie różnicuje pozycję i ryzyko określonych grup obligatariuszy. Co więcej, pierwsi obligatariusze zabezpieczeni hipoteką mogą rościć prawo zarówno do swych starych aktywów, jak i wszystkich nowych aktywów jako zabezpieczenie. Te nowo nabyte aktywa stają się automatycznie częścią wcześniej zabezpieczonych obligacji.

Innym sposobem zabezpieczenia wykonania zobowiązań emitenta obligacji względem obligatariuszy może być ograniczenie udziału akcjonariuszy w zysku.

${ }^{22}$ J. C. Francis, Management of Investments, Second edition, McGraw-Hill, New York, St. Luis 1988, s. 463-464.

${ }^{23}$ T. E. Co peland, J. F. Westo n, Financial Theory and Corporate Policy, Second edition, Addison-Wesley Publishing Company, 1983, s. 447.

${ }^{24}$ H. B i erma n, S. Smidt, Financial Management for Decision Making, Macmillan Publishing Company, New York, Collier Macmillan Publisher, London 1986, s. 339. 
To podporządkowanie maksymalizacji zysków akcjonariuszy bezpieczeństwu wykonania zobowiązań wobec obligatariuszy może wystąpić w związku z pogorszeniem się rentowności przedsiębiorstwa. W takiej sytuacji przyjęcie zasady niewypłacania przez emitenta obligacji rocznej dywidendy gotówkowej powyżej osiagnniętej kwoty zysku netto lub jego określonej części zapewnić może większe bezpieczeństwo finansowe obligatariuszom.

Wzrostowi zabezpieczenia wykonania zobowiązań emitentów obligacji sprzyjać może także zobowiązanie emitenta do okresowego odkupywania pewnej części wartości nominalnej obligacji pozostających w obiegu przed okresem ich wykupu ${ }^{25}$.

\section{ZAKOŃCZENIE}

Za zasadniczy cel artykułu uznano wskazanie na występowanie relacji między zabezpieczeniem rzeczowym w formie zastawu na papierach wartościowych a bezpieczeństwem finansowym przedsiębiorstwa.

Podjęcie rozważań nad zastawem na papierach wartościowych wynikało z potrzeby zwrócenia uwagi na kwestię bezpieczeństwa obrotu gospodarczego z perspektywy zabezpieczenia finansowego wierzycieli i tym samym zmniejszenia ryzyka finansowego. Zabezpieczenie finansowe wierzycieli jest bowiem problemem strategicznym i zarazem nakładającym na przedsiębiorstwo obowiązek opublikowania informacji bieżących odnoszących się m. in. do ustanowienia hipoteki, zastawu lub innego ograniczonego prawa rzeczowego na aktywach o znacznej wartości, przez emitenta papierów wartościowych lub jednostkę od niego zależną.

\section{BIBLIOGRAFIA}

B ierman H., S midt S., Financial Management for Decision Making, Macmillan Publishing Company, New York, Collier Macmillan Publisher, London 1986.

B odi e Z., Kane A., Marku s A. J., Essentials of investments, R. D. Irwin, Inc. Homewood, Boston 1992.

B o d i e Z., Ka n e A., M ar ku s A. J., Investments, R. D. Irwin, Inc. Homewood, Boston 1998.

Copel and T. E., W e st on J. F., Financial Theory and Corporate Policy, Second edition, Addison-Wesley Publishing Company, 1983.

D u r a j N. A., Wieloczynnikowa koncepcja modelu bezpieczeństwa finansowego przedsiębiorstwa, [w:] J. Duraj, A. Sajnóg (red.), Ekonomiczne i pozaekonomiczne czynniki zarzqdzania wartościq przedsiębiorstwa, Wydawnictwo Uniwersytetu Łódzkiego, Łódź 2013.

Fran c i s J. C., Management of Investments, Second edition, McGraw-Hill, New York, St. Luis 1988.

Gn i e w e k E., Prawo rzeczowe, Wydawnictwo C. H. Beck, Warszawa 2003.

${ }^{25}$ Z. B odi e, A. Kane, A. J. Marku s, Essentials of..., op. cit., s. 346. 
G oł a c zy ń sk i J., Zastaw na rzeczach ruchomych, Wydawnictwo C. H. Beck, Warszawa 2002.

Gr zy b o w s ki S., System prawa cywilnego. Prawo zobowiazań - część ogólna, t. III, cz. 1, Wrocław-Warszawa 1981.

Grzybowski S. (red.), System prawa cywilnego. Czesść ogólna, t. 1, Ossolineum, Wrocław 1985.

He ropolit ańs ka I., Prawne zabezpieczenie wierzytelności, [w:] K. Kreczmańska-Gigol (red.), Aktywne zarzqdzanie płynnościa finansowa przedsiębiorstwa, Difin, Warszawa 2010.

Internetowy System Aktów Prawnych - ISAP, http://isap.sejm.gov.pl.

Katne r W. (red.), Prawo cywilne $i$ handlowe $w$ zarysie, Kantor Wydawniczy Zakamycze, Kraków 2004.

Leśniak M., Zastaw bez przeniesienia posiadania przedmiotu zastawu, Kantor Wydawniczy Zakamycze, Kraków 2004.

Obwieszczenie Marszałka Sejmu Rzeczypospolitej Polskiej z dnia 23 kwietnia 2009 r. w sprawie ogłoszenia jednolitego tekstu ustawy o zastawie rejestrowym $i$ rejestrze zastawów, DzU 2009, nr 67, poz. 569.

Obwieszczenie Ministra Finansów z dnia 24 grudnia 2012 r. w sprawie ogłoszenia jednolitego tekstu rozporzadzenia Ministra Finansów w sprawie rejestru zastawów skarbowych oraz Centralnego Rejestru Zastawów Skarbowych, DzU 2013, nr 0, poz. 152.

Obwieszczenie Ministra Finansów z dnia 6 sierpnia 2010 r. w sprawie wysokości kwoty wymienionej $w$ art. 41 par. 1 ustawy - Ordynacja podatkowa, M.P. 2010, nr 59, poz. 781.

Obwieszczenie Ministra Transportu i Gospodarki Morskiej z dnia 12 grudnia 1997 r. w sprawie ogłoszenia jednolitego tekstu ustawy - Kodeks morski, DzU 1998, nr 10, poz. 36.

Pi eloch A., Restrukturyzacja kapitałowa przedsiębiorstw z wykorzystaniem operacji buy-back, [w:] J. D u raj (red.), Instrumenty ksztattowania dochodowości i rentowności przedsiębiorstwa, „Acta Universitatis Lodziensis”, Folia Oeconomica 278, Wydawnictwo Uniwersytetu Łódzkiego, Łódź 2013.

Rozporzqdzenie Ministra Finansów z dnia 19 grudnia 2008 r. w sprawie wzoru oświadczenia o nieruchomościach oraz prawach majątkowych, które moga być przedmiotem hipoteki przymusowej, i rzeczach ruchomych oraz zbywalnych prawach majatkowych, które moga być przedmiotem zastawu skarbowego, DzU 2008, nr 237, poz. 1660.

Rozporzqdzenie Ministra Finansów $z$ dnia 2 grudnia 2011 r. w sprawie wzoru oświadczenia o nieruchomościach oraz prawach majątkowych, które moga być przedmiotem hipoteki przymusowej, i rzeczach ruchomych oraz, zbywalnych prawach majatkowych, które moga być przedmiotem zastawu skarbowego, DzU 2011, nr 274, poz. 1618.

Rozporzqdzenie Ministra Finansów z dnia 22 grudnia 2011 r. zmieniajqce rozporzqdzenie w sprawie rejestru zastawów skarbowych oraz Centralnego Rejestru Zastawów Skarbowych, DzU 2011, nr 293, poz. 1730.

Rozporzqdzenie Ministra Finansów z dnia 24 grudnia 2002 r. w sprawie rejestru zastawów skarbowych oraz Centralnego Rejestru Zastawów Skarbowych, DzU 2002, nr 240, poz. 2068.

Rozporzadzenie Ministra Finansów z dnia 25 sierpnia 2005 r. w sprawie wzoru oświadczenia o rzeczach ruchomych oraz zbywalnych prawach majatkowych, które moga być przedmiotem zastawu skarbowego, DzU 2005, nr 166, poz. 1390.

Rozporzqdzenie Ministra Finansów z dnia 31 grudnia 1997 r. w sprawie wykonania niektórych przepisów ustawy - Ordynacja podatkowa, DzU 1997, nr 162, poz. 1124.

Rozporzqdzenie Ministra Infrastruktury z dnia 14 czerwca 2004 r. w sprawie trybu dokonywania $w$ dowodach rejestracyjnych pojazdów mechanicznych adnotacji o ustanowieniu zastawu rejestrowego, DzU 2004, nr 145, poz. 1542.

Rozporzqdzenie Ministra Sprawiedliwości z dnia 10 marca 2009 r. w sprawie przeprowadzenia sprzedaży przedmiotu zastawu rejestrowego $w$ drodze przetargu publicznego, DzU 2009, nr 45 , poz. 371. 
Rozporzqdzenie Ministra Sprawiedliwości z dnia 11 grudnia 2008 r. w sprawie określenia wzorów urzędowych formularzy wniosków o wpis do rejestru zastawów, DzU 2008, nr 229, poz. 1532 .

Rozporzqdzenie Ministra Sprawiedliwości z dnia 11 grudnia 2008 r. w sprawie warunków organizacyjno-technicznych dotyczacych formy wniosków i dokumentów oraz ich składania do sqdów prowadzacych rejestr zastawów i do centralnej informacji o zastawach rejestrowych droga elektroniczna, a także orzeczeń, odpisów, zaświadczeń i informacji doręczanych wnioskodawcom ta droga przez sqdy oraz centralnq informację, DzU 2008, $\mathrm{nr} 229$, poz. 1535.

Rozporzqdzenie Ministra Sprawiedliwości z dnia 11 grudnia 2008 r. zmieniajace rozporzqdzenie w sprawie szczegótowej organizacji i sposobu prowadzenia rejestru zastawów, DzU 2008, nr 229, poz. 1533.

Rozporzqdzenie Ministra Sprawiedliwości z dnia 11 grudnia 2008 r. zmieniajq̨ce rozporzqdzenie $w$ sprawie ustroju i organizacji centralnej informacji o zastawach rejestrowych oraz szczegótowych zasad udzielania informacji, wydawania odpisów i zaświadczeń, DzU 2008, nr 229, poz. 1534.

Rozporzqdzenie Ministra Sprawiedliwości z dnia 15 października 1997 r. w sprawie określenia wzorów urzędowych formularzy, DzU 1997, nr 155, poz. 1018.

Rozporzqdzenie Ministra Sprawiedliwości z dnia 15 października 1997 r. w sprawie szczegótowej organizacji i sposobu prowadzenia rejestru zastawów, DzU 1997, nr 134, poz. 892.

Rozporzadzenie Ministra Sprawiedliwości z dnia 15 października 1997 r. w sprawie ustroju i organizacji centralnej informacji o zastawach rejestrowych oraz szczegótowych zasad udzielania informacji, wydawania odpisów i zaświadczeń, DzU 1997, nr 134, poz. 893.

Rozporzqdzenie Ministra Sprawiedliwości z dnia 23 grudnia 2004 r. zmieniajace rozporzadzenie $w$ sprawie ustroju i organizacji centralnej informacji o zastawach rejestrowych oraz szczegótowych zasad udzielania informacji, wydawania odpisów i zaświadczeń, DzU 2004, nr 285, poz. 2867.

Rozporzqdzenie Ministra Sprawiedliwości z dnia 30 grudnia 1997 r. w sprawie wysokości opłat za informacje, odpisy i zaświadczenia wydawane przez Centralnq Informację o Zastawach Rejestrowych, DzU 1998, nr 2, poz. 4.

Rozporzqdzenie Ministra Transportu i Gospodarki Morskiej z dnia 22 września 2000 r. w sprawie trybu dokonywania $w$ dowodach rejestracyjnych pojazdów mechanicznych adnotacji o ustanowieniu zastawu rejestrowego, DzU 2000, nr 82, poz. 934.

S i kors ki G., Sytuacja prawna zastawnika w prawie polskim, Doktoraty Wydziału Prawa i Administracji Uniwersytetu Mikołaja Kopernika w Toruniu, Torun 2010.

S kąp ski J., Zastaw na rzeczach ruchomych wedtug kodeksu cywilnego. Zagadnienia wybrane, „Studia Cywilistyczne” 1966, t. VIII.

S ok al P., Zastaw zwykty i rejestrowy na akcjach, Wolters Kluwer Polska Sp. z o.o., Warszawa 2011.

Ustawa z dnia 15 marca 2007 r. o zmianie ustawy - Kodeks postępowania cywilnego, ustawy - Kodeks postępowania karnego oraz o zmianie niektórych innych ustaw, DzU 2007, nr 112, poz. 766.

Ustawa z dnia 2 kwietnia 2004 r. o niektórych zabezpieczeniach finansowych, DzU 2004, nr 91, poz. 871, implementująca do prawa polskiego Dyrektywe Nr 2002/47/WE Parlamentu i Komisji Europejskiej z 06.06.2002 r. w sprawie uzgodnień dotyczqcych zabezpieczeń finansowych.

Ustawa z dnia 20 listopada 2009 r. o zmianie ustawy o zastawie rejestrowym i rejestrze zastawów, DzU 2009, nr 215, poz. 1663.

Ustawa z dnia 23 kwietnia 1964 r. - Kodeks cywilny, DzU 1964, nr 16, poz. 93.

Ustawa z dnia 24 maja 2000 r. o zmianie ustawy - Kodeks postępowania cywilnego, ustawy o zastawie rejestrowym i rejestrze zastawów, ustawy o kosztach sqdowych $w$ sprawach cywilnych oraz ustawy o komornikach sqdowych i egzekucji, DzU 2000, nr 48, poz. 554. 
Ustawa z dnia 28 listopada 2003 r. o zmianie ustawy - Prawo o ustroju sqdów powszechnych, ustawy o prokuraturze, ustawy - Prawo o ustroju sadów wojskowych oraz niektórych innych ustaw, DzU 2003, nr 228, poz. 2256.

Ustawa z dnia 29 czerwca 1995 r. o obligacjach, DzU 2001, nr 120, poz. 1300 z późn. zm.

Ustawa z dnia 29 lipca 2005 r. o obrocie instrumentami finansowymi, DzU 2005, nr 183, poz. 1538.

Ustawa z dnia 29 sierpnia 1997 r. - Prawo bankowe, DzU 2012, nr 0, poz. 1376 z późn. zm.

Ustawa z dnia 4 września 2008 r. o zmianie ustawy o obrocie instrumentami finansowymi oraz niektórych innych ustaw, DzU 2009, nr 165, poz. 1316.

Ustawa z dnia 6 grudnia 1996 r. o zastawie rejestrowym i rejestrze zastawów, DzU 1996, nr 149, poz. 703.

Wyrok Trybunału Konstytucyjnego z dnia 1 lutego 2005 r. sygn. akt SK 62/03, DzU 2005, nr 25, poz. 215.

Zarzqdzenie Ministra Transportu i Gospodarki Morskiej z dnia 2 października 1997 r. w sprawie trybu dokonywania $w$ dowodach rejestracyjnych pojazdów mechanicznych adnotacji o ustanowieniu zastawu rejestrowego, M.P. 1997, nr 73, poz. 696.

\section{Natasza Duraj}

\section{PLEDGE ON SECURITIES AND FINANCIAL SECURITY OF ENTERPRISE}

The article analyzes the relationship between collateral in the form of a pledge on securities and financial security of an enterprise. Purpose of the study was considered to be important from the point of view of the scientific research's needs as well as the business practice because of the essential role and the significance of the pledge in financial support of a company. The paper presents issues concerning the nature and the types of pledge on securities, as well as the basic rights and obligations of the pledger and the pledgee. Moreover, it describes the issues that are commonly encountered in the economic practice relating to the methods of securing the execution of commitments.

Key words: financial security of a company, economic turnover security, pledge on securities, pledge on shares, financial security of the creditors. 